\title{
The Effect of Adding Black Soldier Fly (BSF) Larvae (Hermetia illucens L.) Flour on the Characteristics of Tortilla Chips
}

\author{
I Gusti Ayu Krisma Widya Saraswati ${ }^{1}$, I Gede Arie Mahendra Putra ${ }^{1}$ \\ and Luh Putu Wrasiati ${ }^{2}$
}

${ }^{1}$ Departmentof Food Technology, Faculty of Agricultural Technology, Unud, Indonesia

${ }^{2}$ Department of Industrial Agricultural Technology, Faculty of Agricultural Technology, Unud, Indonesia

*Corresponding author

\section{Ke y words \\ BSF Larvae Flour, Characteristic, Tortilla Chips \\ Article Info \\ Received: \\ 10 November 2021 Accepted: 06 December 2021 Available Online: 10 December 2021}

\section{A B S T R A C T}

This research aimed to determine the effect of Black Soldier Fly (BSF) larvae flour added on the characteristic of tortilla chips. The study was designed using an experimental method which is Completely Randomized Design (CRD) with treatment of adding larvae BSF flour $(0 \%, 5 \%, 10 \%, 15 \%$, and 20\%) that was repeated 3 times to obtained 15 experimental units. The data obtained were analyzed by means of variance and if the treatment had a significant effect, then proceed with the Tukey test except for total plate count analyzed using descriptive test. The Observed variable were moisture content, ash content, protein content, fat content, carbohydrate content, crude fiber, total plate count (TPC) and sensory evaluation such as color, texture, flavour, taste and overall acceptance with hedonic test and color also texture with scoring test also using effective index to obtained the best treatment. The results showed that adding 20\% BSF larvae flour is the best treatment to get the best characteristic of tortilla chips BSF larvae with moisture content $1,84 \pm 0,19 \%$, ash content $8,35 \pm 0,08 \%$, protein content $19,45 \pm 0,42 \%$, fat content $22,56 \pm 0,57 \%$, carbohydrate content $47,80 \pm 0,94 \%$, crude fiber $5,34 \pm 0,20 \%$, total plate count (TPC) $2,9 \times 10^{3}$ and sensory evaluation of hedonic color (3.0) and texture (3.5) with criteria neutral, and taste (4.0), aroma (3.8), and overall acceptance (4.1) with the criteria of liking and the color scoring test (1.4) with the criteria of very brown and the scoring test texture $(3,2)$ with the usual criteria.

\section{Introduction}

To meet the world's population's food needs, food production must be increased by at least twice the current total food production. Furthermore, the global level has reached 1 billion million people, indicating that there are still many malnourished people in the world. This condition indicates the need for food production solutions to avoid increasing food scarcity in the community. One of them is the consumption of insects as food. Eating insects, 
also known as entomophagy, is not a new phenomenon in society. In Indonesia, there are several insect-based foods available, including sago caterpillars, fried crickets, and a variety of other insects. Moreover, the larvae Black Soldier Fly (BSF) is one insect that has not been polarized in the food field.

In terms of nutrition, BSF larvaes are appealing insects because they contain a variety of micronutrients (iron, zinc, calcium) as well as macronutrients (protein, fat, chitin).

The amino acid profile of Larvae BSF is said to be by the WHO reference standards, indicating that Larvae BSF is capable of being a good protein alternative for human consumption. Several studies have also indicated that Larvae BSF has a high protein content. Antimicrobial activity of saturated fatty acid, specifically lauric acid (C12:0), against gram-positive bacteria (Rabani, Cheatsazan, and Davani, 2019). However, no research has been conducted on the use of Larvae BSF as a food product for humans, so the authors are interested in researching the use of insects, specifically Larvae BSF, to create food products that humans can consume. Chips are one of the food products made from popular snacks; additionally, the manufacturing process is simple and requires only basic equipment. Based on the ingredients in Larvae BSF and their processing into food products, particularly chips, the benefits obtained are enormous, especially the higher protein content.

\section{Materials and Methods}

This research was conducted in the Food Processing Laboratory, Food Analysis Laboratory, Faculty of Agricultural Technology, Udayana University, and The Laboratory of Basic Sciences of Warmadewa University. The study was conducted from August to October 2021.
The ingredient used in this study is Larvae BSF flour obtained from PT. Bala Biotech Indonesia, corn grits, salt, the baking powder obtained from UD. Fenny Denpasar and water. The chemicals used in the study were technical Hexane, Kjeldahl tablets, concentrated $\mathrm{H} 2 \mathrm{SO} 4$, equates, $\mathrm{NaOH}$, PP, boric acid, HCL, and alcohol.

The tools used in this study are ovens, mixers, basins, spoons, analytical scales, aluminum foil, tissues, dedicators, porcelain cups, Soxhlets, Whatman paper No. 42, destilators Erlenmeyer, test tubes, measuring cups, baker glasses, centrifuge tubes, centrifuge, vortex, blender, paper plates, siends.

The research design of this study is using Completely Randomized Design (CRD) is applied in this research with the treatment of the addition of BSF Larvae flour. It is repeated three times, therefore 15 experimental units are obtained. The addition of larvae flour consisted of 5 levels as follows:

P0: The addition of $0 \%$ BSF larvae flour

P0: The addition of 5\% BSF larvae flour

P0: The addition of $10 \%$ BSF larvae flour

P0: The addition of $15 \%$ BSF larvae flour

P0: The addition of $20 \%$ BSF larvae flour

The making of BSF Larvae flour was started with boiling. The BSF larvae flour was lied in shaking and boiled with hot water 5-10 minutes, then it was lined and dried by the oven with a temperature of $50{ }^{\circ} \mathrm{C}$ in 9 to 12 minutes. The process was continued by grounding the BSF larvae with the ground machine and shaking with 100 mesh until it smooth (Harlystiarini, 2017). In making Tortilla Chips BSF Larvae flour used several ingredients such as grits corn, BSF larvae 
flour, and any additional materials such as salt, baking powder, and water. The BSF larvae flour is added in by considering the level of addition that has been decided, then mixed with extra materials. The mixing process is done with a mixer, if the material has been mixed evenly printing with the shape and is surprised by the roasting process (Wahyuni, 2008).

Variables observed in the study included analysis of moisture content, ash levels, protein levels, fat levels, carbohydrate levels, coarse fiber levels referring to Sudarmadji et al., (1997), sensory characteristics that include hedonic tests of color, taste, aroma, texture, overall acceptance as well as a score test of the color and texture that refers to (Soekarto, 1985) and the Total Microbial Test (Total Plate Count) referring to Sukmawati et al., (2018).

\section{Results and Discussion}

The average value of moisture content, ash content, fat content, protein levels, carbohydrate content, and coarse fiber from ingredients namely larvae flour and corn grits can be seen in Table 1.

\section{Moisture Contents}

The results of the means of variance showed that the addition of BSF larvae flour had a significance effect $(\mathrm{P}<0.05)$ on the moisture content of the BSF larvae tortilla chips produced. The results of the moisture content of BSF larvae tortilla chips can be seen in Figure 1. The percentage of the moisture content of larvae chips tortillas ranges from $1.84 \%-2.25 \%$. The highest percentage was obtained in the P1 treatment (Addition of BSF larvae Flour by $5 \%$ ) which is $2.25 \%$ while the lowest percentage of moisture content is obtained in $\mathrm{P} 4$ treatment (Addition of BSF larvae flour as much as $20 \%$ ) which is $1.84 \%$.
These results show that increasingly. Many additions of BSF larvae flour then the moisture content of tortilla chips produced will be lower, it can also be seen from the material used. According to the results of the material, testing conducted the moisture content of BSF larvae flour has a lower moisture content of $2.60 \%$ compared to corn grits which are $3.10 \%$, therefore the more BSF larvae flour added will cause the moisture content of tortilla chips. The result is getting lower. The results of the material testing can be seen in Table 1. According to Winarno (2002) Indications of optimum stability level in the material are achieved when the moisture content of the material ranges from $3-7 \%$, in low moisture chip products produced because it has gone through the frying process so that the free water contained in the material is released and causes the moisture content of the resulting product to below.

Based on SNI 01-2886-2000 on extruding snack quality requirements, chips included in snacks stand out and the moisture content range of extruded snack products is a maximum of $4 \%-5 \%$. The moisture content of BSF larvae tortilla chips based on Figure 1 ranges from $1.84 \%-2.25 \%$ so that the moisture content produced in larvae chip tortillas meets the quality standards of snacks extruded according to SNI 01-2886-2000 (BSN, 2000).

\section{Ash Contents}

The results of the analysis of variance showed that the addition of BSF larvae flour had a very significance effect $(\mathrm{P}<0.01)$ on the ash level of the resulting tortilla chips. The results of the ash level of BSF larvae tortilla chips can be seen in Figure 2. The percentage rate of ash BSF larvae tortilla chips ranges from 5.42 $\%-8.35 \%$. The highest percentage is obtained in the treatment of $\mathrm{P} 4$ (Addition of BSF Larvae Flour by 20\%) which is $8.35 \%$ while 
the lowest percentage of ash levels is obtained in the treatment of P0 (No Addition of BSF Larvae Flour) is $5.42 \%$. The results showed that the more addition of BSF larvae flour, the higher the level of ash chip tortillas produced, can also be seen from the material used. According to the results of material testing conducted, the ash content of BSF larvae flour has an ash content of $13.09 \%$, higher than corn grit which is $2.02 \%$, so the more BSF larvae flour added will cause the ash content of tortilla chips produced higher.

The level of ash in food products indicates the mineral content in the product. Mineral components are usually calcium, potassium, sodium, iron, manganese, and iodine. Minerals have a function as a building and regulatory substances in the body, such as the mineral type calcium has a function in bone formation and nutrition (Winarno, 2002). According to Fahmi et al., (2017), BSF larvae contain several types of minerals such as $\mathrm{Mn}$ by 0.05 $\mathrm{mg} / \mathrm{g}, \mathrm{Zn}$ by $0.09 \%$, Fe by $0.68 \%, \mathrm{Cu}$ by $0.01 \%, \mathrm{P}$ by $0.13 \%$, Ca by $55.65 \%, \mathrm{Mg}$ by $3.50 \%$, Na by $13.71 \%$ and $\mathrm{K}$ by $10 \%$. When compared to similar studies tortilla chips from larvae flour have value.

Ash levels are higher than studies conducted by Anindita (2017) which reported that tortillas from cricket flour contain $4.19 \%$ ash levels, so it can be known that the minerals contained in larvae chip tortillas are higher.

\section{Fat Contents}

The results of the analysis of variance showed that the addition of BSF larvae flour had a significance effect $(\mathrm{P}<0.05)$ on the fat content of the tortilla chips produced. The results of the fat content of BSF larvae tortilla chips can be seen in Figure 3. The percentage of fat levels of larvae chip tortillas ranges from $20.57 \%-22.56 \%$. The highest percentage was obtained in the P4 treatment (Addition of BSF
Larvae Flour by $20 \%$ ) which is $22.56 \%$ while the lowest percentage of fat content is obtained in the P0 treatment (No Addition of BSF Larvae Flour) which is $20.57 \%$. The results showed that the more addition of BSF larvae flour, the higher the fat content of tortilla chips produced, it can also be seen from the ingredients used. According to the results of material testing conducted, the fat content of larvae flour BSF has a fat content of $7.39 \%$, higher than corn grits which is $3.45 \%$, so the more larvae flour BSF added will cause the fat content of tortilla chips produced the higher, it is proven by treatment without the addition of BSF larvae flour produces the lowest fat content. In addition, the frying process is also another factor that increases fat content in larvae chip tortillas.

Based on SNI 01-2886-2000 on the quality requirements of extrudate snacks, chips are included in extrudate snacks and the range of fat content of extrudate snack products with a frying process is a maximum of $38 \%$. The fat content of larvae chips tortillas based on Figure 2 ranges from $20.57 \%-22.56 \%$ so that the fat content produced in larvae chip tortillas all treatments already meet the quality standards of extrudate snacks. SNI 01-28862000 (BSN, 2000).

\section{Protein Contents}

The results of the analysis of variance showed that the addition of BSF larvae flour had a very significance effect $(\mathrm{P}<0.01)$ on the levels of BSF larvae tortilla chips produced. The results of BSF larvae tortilla chips protein levels can be seen in Figure 4. The percentage of BSF larvae tortilla chips protein contents ranges from $8.99 \%-19.45 \%$. The highest percentage was obtained in the $\mathrm{P} 4$ treatment (Addition of BSF Larvae Flour by 20\%) which is $19.45 \%$ while the lowest percentage of protein levels is obtained in the P0 treatment (No Addition of BSF Larvae Flour) 
which is $8.99 \%$. The results showed that the more addition of BSF larvae flour, the higher the content of protein tortilla chips produced, it can also be seen from the ingredients used. According to the results of material testing

Carried out, the protein content of larvae BSF flour by $57.86 \%$, higher than corn grits which are $11.24 \%$, so the more larvae BSF flour added will cause protein tortilla chips. The result is getting higher. This suggests that added BSF larvae flour contributes to protein tortilla chips. In addition, the same thing was also reported by Fahmi et al., (2007) which stated that larvaes have a fairly high protein content of $44.26 \%$.

Protein is a substance in food that is very important for the body, protein has the potential in the formation of new tissues to replace and maintain body tissues (Winarno, 2002). When compared to other studies, tortilla chips made with the addition of BSF larvae flour have higher protein levels. Rohmayanti et al., (2019) reported that tortilla chips made with the addition of soy sauce pulp flour by $18.2 \%$ have the protein content of $14.76 \%$, so the addition of BSF larvae flour in its application into tortilla chips is very good for increasing product protein.

\section{Carbohydrate Contents}

The results of the analysis of variance showed that the use of BSF larvae flour in the making of larvae chip tortillas had a very significane effect $(\mathrm{P}<0.01)$ on the characteristics of carbohydrates produced.

The results of the carbohydrate BSF larvae tortilla chips can be seen in Figure 5. The percentage of carbohydrate tortilla chips BSF larvae produced is between $47.80 \%-62.69 \%$. The highest percentage results were obtained in the P0 treatment (Without the Addition of BSF Larvae) with a rate of $62.69 \%$, while the lowest percentage was in the $\mathrm{P} 4$ treatment (Addition of BSF Larvae Flour by $20 \%$ ) with a result of $47.80 \%$. The results showed that the highest carbohydrate contribution came from corn grits, so the higher the addition of BSF larvae flour will lower the levels of carbohydrates produced from BSF larvae tortilla chips. Based on the analysis of raw materials, the carbohydrate content in corn grits reached $80.19 \%$, while the carbohydrate content in BSF larvae flour raw materials was lower at $20.70 \%$. These results prove that the increasing concentration of larvae flour will lower the carbohydrate content of tortilla chips.

Carbohydrates become one of the important food components in the body, namely as an energy producer (Sediaoetama, 2008). The presence of carbohydrates in food products although snacks are very important, but the level of carbohydrates in extrudate foods is still not regulated in SNI. Carbohydrate levels in chip tortillas range from $47.80 \%-62.69 \%$ is quite high when compared to Rohmayanti et al., (2019) which reported that tortilla chips made with the addition of soy sauce pulp flour had a carbohydrate content of $57.17 \%$. Therefore, the addition of BSF larvae flour ranging from $5 \%$ to $20 \%$ still contributes good carbohydrates to tortilla chips BSF larvae.

\section{Crude Fiber Content}

The results of the analysis of variance showed that the addition of BSSF larvae flour had a very significance effect $(\mathrm{P}<0.01)$ against the crude fiber of BSF larvae tortilla chips. The crude fiber content results of BSF larvae tortilla chips can be seen in Figure 6.

The percentage of the crude fiber content of BSF larvae chips tortillas ranges from $2.57 \%$ $5.34 \%$. The highest result was in the $\mathrm{P} 4$ treatment (Addition of BSF Larvae Flour by $20 \%$ ) is $5.34 \%$. The lowest percentage of 
crude fiber content is found in the $\mathrm{P} 0$ treatment (No Addition of BSF Larvae Flour) is $2.57 \%$. Based on the results of raw material testing, the crude fiber content of raw materials, BSF larvae flour has a greater value of $7.30 \%$ compared to corn grits which are only $4.79 \%$ so it can be proven that the higher the addition of BSF larvae flour has an impact in the form of increasing the crude fiber of larvae chip tortilla products.

Food products with crude fiber content that is relatively low in calories are considered able to reduce the risk of obesity (Piliang and Djojosoebagio, 2002).

The crude fiber content in tortilla chips has not been regulated in SNI, but Panjaitan et al., (2020) in the producing of tortilla chips with the addition of seaweed, reported that by adding seaweed the coarse fiber content of tortilla chips has a range between $1.34 \%$ $1.75 \%$.

\section{Determining the Best Treatment with an Effectiveness Index}

The effectiveness index test is a method of determining the best treatment in producing BSF larvae tortilla chip with the best proximate levels based on (De Garmo et al., 1984). Variables observed in this test are moisture content, ash content, protein content, fat content, carbohydrate content, and crude fiber content. The results of the BSF larvae tortilla chip effectiveness index can be seen in Table 2.

The best treatment is indicated by the highest number of yield values. Table 2 shows that the P4 treatment of the addition of BSF larvae flour by $20 \%$ has the highest value of 0.66 , thus the P4 treatment (addition of BSF larvae flour by $20 \%$ ) becomes the best treatment in producing proximate levels in BSF larvae tortilla chip.

\section{Total Plate Count (TPC)}

Total Plate Count (TPC) testing on larvae chip tortillas is done descriptively. The results of TPC testing on larvae tortilla chips can be seen in Table 3 . BSF larvae tortilla chip have a range of TPC from P0 (No Addition of BSF larvae Flour) to P4 (BSF larvae Flour Addition 20\%) which is $2.5 \times 10^{2}-2.9 \times 10^{3}$. The results also showed that the greater the addition of BSF larvae flour increased the TPC number, according to the results. TPC of each raw material, larvae flour has a TPC number of $2.4 \times 10^{3}$ compared to the TPC number of corn grits which is $1.8 \times 10^{2}$.

Based on SNI 01-2886-2000 on the quality requirements of extrudate snacks, chips are included in extrudate snacks and have a maximum requirement of total plate numbers or Total Plate Count (TPC) of $1.0 \times 10^{4}$. Therefore, the overall treatment in the manufacture of BSF larvae tortilla chips and from each raw material, namely BSF larvae flour and corn grits is still below the maximal standard of SNI 01-2886-2000.

\section{Sensory Evaluation}

Evaluation of the sensory properties of larvae chip tortillas is hedonic testing of taste, aroma, color, texture, and overall reception as well as scoring tests on color and texture. The average value of the larvae chips tortilla test against color, aroma, texture, taste, and overall reception can be seen in Table 4 while the average value of the larvae chips tortilla tortillas test against color and texture can be seen in Table 5.

\section{Color}

The results of the analysis of variance of treatments added BSF larvae flour BSF had a significance effects $(\mathrm{P}<0.01)$ against the color of the resulting BSF larvae tortilla chips. The 
panelist's average color (hedonic) is obtained at the P0 treatment (without the addition of BSF larvae flour) which is 4.6 (very like) and the lowest average value is obtained on the P4 treatment (20\% addition of BSF larvae flour) which is 3.0 (neutral). This shows that the more addition of BSF larvae flour will decrease the level of panelists' fondness for the color of the tortilla chips produced.

This is also due to the increasing addition of BSF larvae flour, the color of the tortilla chips that will be produced will getting brown and dark. According to Muchtadi et al., (1992) color assessment of food, the product is important because the color parameter is one of the parameters used to determine the quality of the material, the addition of BSF larvae flour will produce different colors.

\section{Aroma}

The results of the analysis of variance of treatment of the addition of BSF larvae flour had a significance effect $(\mathrm{P}<0.05)$ to the aroma of BSF larvae tortilla chip produced. The average panelist's average aroma (hedonic) was obtained at the P0 treatment (No Addition of BSF Larvae Flour) which is 4.5 (likes) and the lowest average value is obtained on the P4 treatment (Addition of $20 \%$ BFS Larvae Flour) which is 3.8 (likes). The added value of BSF larvae flour decreases the average value of panelists' fondness for the aroma of the resulting BSF larvae tortilla chip, but if grouped on the criteria of liking the average value produced in hedonic testing of the aroma of the resulting BSF larvae tortilla chip is included in the "like" criteria. This indicates that the panelists still like and receive the aroma of BSF larvae tortilla chip produced by the treatment of the addition of BSF larvae flour. According to Mudjajanto and Yulianti (2004) aroma is one of the factors used as a determinant of the level of preference of panelists to a product.

\section{Texture}

The results of the analysis of variance of treatments of the addition of BSF larvae flour had a very significance effect $(\mathrm{P}<0.01)$ to the texture of the BSF larvae tortilla chip produced. The texture is one of the factors that can be used to determine the level of consumer fondness for a food product.

Factors that affect the texture of the chip tortillas produced are also determined by the ingredients used. The panelist's average of texture (hedonic) was obtained at the P0 treatment (No Addition of BSF larvae Flour) which is 4.6 (very like) and the lowest average value is obtained on the $\mathrm{P} 4$ treatment (Addition of $20 \%$ BSF larvae Flour) which is 3.5 (neutral). This indicates that the more addition of BSF larvae flour will decrease the level of panelist fondness for the texture of the tortilla chips produced.

\section{Taste}

The results of the analysis of variance of treatment of the addition of BSF larvae flour had a significance effect $(\mathrm{P}<0.05)$ to the taste of the BSF larvae tortilla chip produced.

The panelist's average taste (hedonic) is highest obtained at the P0 treatment (without the addition of BSF larvae flour) which is 4.6 (very like) and the lowest average value is obtained at the P4 treatment (Addition of $20 \%$ BSF larvae Flour) which is 4.0 (likes). This is likely because the panelists are familiar with the taste of tortilla chips products that are used to the taste of tortilla chips. Made from corn compared to the taste of tortilla chips products made with the addition of BSF larvae flour. 
Table.1 Average Value of Moisture content, Ash Content, Fat Content, Protein Content, Carbohydrate Content As well as Crude Fiber Content in BSF Larvae Flour and Corn Grits.

\begin{tabular}{|c|c|c|}
\hline Component & BSF Larvae Flour & Corn Grits \\
\hline Water (\%) & 2,60 & $\mathbf{3 , 1 0}$ \\
\hline Ash (\%) & 13,09 & $\mathbf{2 , 0 2}$ \\
\hline Fat (\%) & 7,39 & $\mathbf{3 , 4 5}$ \\
\hline Protein (\%) & 57,86 & $\mathbf{1 1 , 2 4}$ \\
\hline Carbohydrates (\%) & 20,70 & $\mathbf{8 0 , 1 9}$ \\
\hline Coarse Fiber (\%) & 7,30 & $\mathbf{4 , 7 9}$ \\
\hline Total Plate Count & $\mathbf{2 , 4} \times \mathbf{1 0}^{\mathbf{3}}$ & $\mathbf{1 , 8} \times \mathbf{1 0}$ \\
\hline
\end{tabular}

Table.2 Best treatment testing results with Effectiveness Index

\begin{tabular}{|c|c|c|c|c|c|c|c|c|}
\hline & & & & & Variable & & Total \\
\hline & & Water & Ash & Protein & Fat & Carbohydrate & Crude Fiber & \\
\hline & & Content & Content & Content & Content & Content & Content & \\
\hline & BN & 5,6 & 4 & 5,8 & 4,2 & 5,4 & 3,4 & $\mathbf{2 8 , 4}$ \\
\hline P0 & Ne & $-2,04$ & 0,34 & 0,10 & $-0,46$ & 0,09 & 0,12 & $\mathbf{1 , 0 0}$ \\
\hline & Nh & $-0,40$ & 0,05 & 0,02 & $-0,07$ & 0,02 & 0,04 & $\mathbf{- 0 , 3 4}$ \\
\hline P1 & Ne & 0,16 & 0,29 & 0,16 & 0,65 & 0,79 & 0,09 & \\
\hline & Nh & 0,03 & 0,04 & 0,03 & 0,10 & 0,15 & 0,01 & $\mathbf{0 , 3 6}$ \\
\hline & Ne & 0,43 & 0,46 & 0,40 & 0,59 & 0,60 & 0,37 & \\
\hline & Nh & 0,08 & 0,06 & 0,08 & 0,09 & 0,11 & 0,04 & $\mathbf{0 , 4 8}$ \\
\hline & Ne & 0,94 & 0,60 & 0,63 & 0,12 & 0,35 & 0,67 & \\
\hline P3 & Nh & 0,19 & 0,09 & 0,13 & 0,02 & 0,07 & 0,08 & $\mathbf{0 , 5 6}$ \\
\hline & Ne & 1,00 & 1,00 & 1,00 & 0,00 & 0,00 & 1,00 & \\
\hline & Nh & $\mathbf{0 , 2 0}$ & $\mathbf{0 , 1 4}$ & $\mathbf{0 , 2 0}$ & $\mathbf{0 , 0 0}$ & $\mathbf{0 , 0 0}$ & $\mathbf{0 , 1 2}$ & $\mathbf{0 , 6 6}$ \\
\hline
\end{tabular}

Description : $\mathrm{P} 0=$ No addition of larvae flour, $\mathrm{P} 1=$ Addition of $5 \%$ larvae flour, $\mathrm{P} 2$ = Addition of $10 \%$ larvae flour, P3 = Addition of $15 \%$ larvae flour, $\mathrm{P} 4=$ Addition of $20 \%$ larvae flour.

Table.3 The average value of larvae chips hedonic tortilla test against color, aroma, texture, taste, and overall acceptance

\begin{tabular}{|c|c|c|c|c|c|}
\hline Treatment & Color & Aroma & Texture & Taste & $\begin{array}{c}\text { Overall } \\
\text { Acceptance }\end{array}$ \\
\hline P0 & $4,6 \mathrm{a}$ & $4,5 \mathrm{a}$ & $4,6 \mathrm{a}$ & $4,5 \mathrm{a}$ & $\mathbf{4 , 5 a}$ \\
\hline P1 & $4,2 \mathrm{ab}$ & $4,4 \mathrm{ab}$ & $4,4 \mathrm{a}$ & $4,3 \mathrm{ab}$ & $\mathbf{4 , 2 a b}$ \\
\hline P2 & $4,0 \mathrm{~b}$ & $4,3 \mathrm{ab}$ & $4,1 \mathrm{ab}$ & $4,4 \mathrm{ab}$ & $\mathbf{4 , 5 a b}$ \\
\hline P3 & $3,0 \mathrm{c}$ & $4,0 \mathrm{ab}$ & $3,6 \mathrm{~b}$ & $4,0 \mathrm{ab}$ & $\mathbf{3 , 9 a b}$ \\
\hline P4 & $\mathbf{3 , 0 c}$ & $\mathbf{3 , 8 b}$ & $\mathbf{3 , 5 b}$ & $\mathbf{4 , 0 b}$ & $\mathbf{4 , 1 b}$ \\
\hline
\end{tabular}

Description: The same letter below the average value in the column indicates a no different treatment, $(\mathrm{P}>0.05)$. $\mathrm{P} 0$ $=$ No addition of larvae flour, $\mathrm{P} 1=$ Addition of $5 \%$ larvae flour, $\mathrm{P} 2=$ Addition of $10 \%$ larvae flour, $\mathrm{P} 3=$ Addition of $15 \%$ larvae flour, $\mathrm{P} 4=$ Addition of $20 \%$ larvae flour.

Hedonic criteria: $1=$ Very dislike, $2=$ Dislike, $3=$ Neutral, $4=$ Like, $5=$ Very Like. 
Table.4 The average value of tortilla chips larvae score against color and texture

\begin{tabular}{|c|c|c|}
\hline Treatment & Color & Texture \\
\hline No Addition of BSF Larvae Flour & $4,7 \mathrm{a}$ & $\mathbf{3 , 9 a}$ \\
\hline The addition of 5\% of BSF Larvae Flour & $3,2 \mathrm{~b}$ & $\mathbf{3 , 7 a b}$ \\
\hline The addition of 10\% of BSF Larvae Flour & $2,5 \mathrm{c}$ & $\mathbf{3 , 6 a b}$ \\
\hline The addition of 15\% of BSF LarvaeFlour & $1,9 \mathrm{~d}$ & $\mathbf{3 , 5 a b}$ \\
\hline The addition of 20\% of BSF Larvae Flour & $\mathbf{1 , 4 e}$ & $\mathbf{3 , 2 b}$ \\
\hline
\end{tabular}

Description: The same letter below the average value in the column indicates a no different treatment $(\mathrm{P}>0.05)$ treatment. Color scoring criteria: $5=$ very yellow; $4=$ yellow; $3=$ brownish yellow; $2=$ chocolate; $1=$ very brown Texture scoring criteria: $5=$ very crunchy; $4=$ crispy; $3=$ ordinary; $2=$ hard; $1=$ very hard

Fig.1 Moisture content of BSF larvae tortilla chips

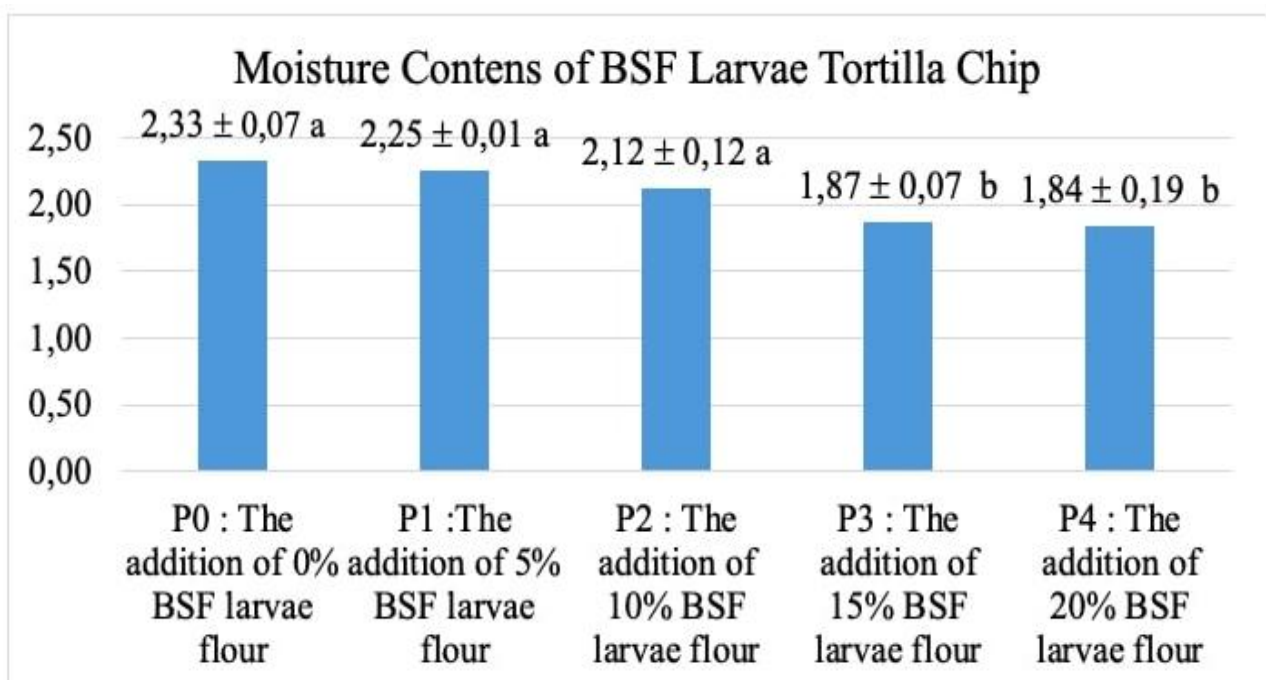

Description: The same letter below the average value in the column indicates a no different treatment, $(\mathrm{P}>0.05)$

Fig.2 Ash content of BSF larvae tortilla chips

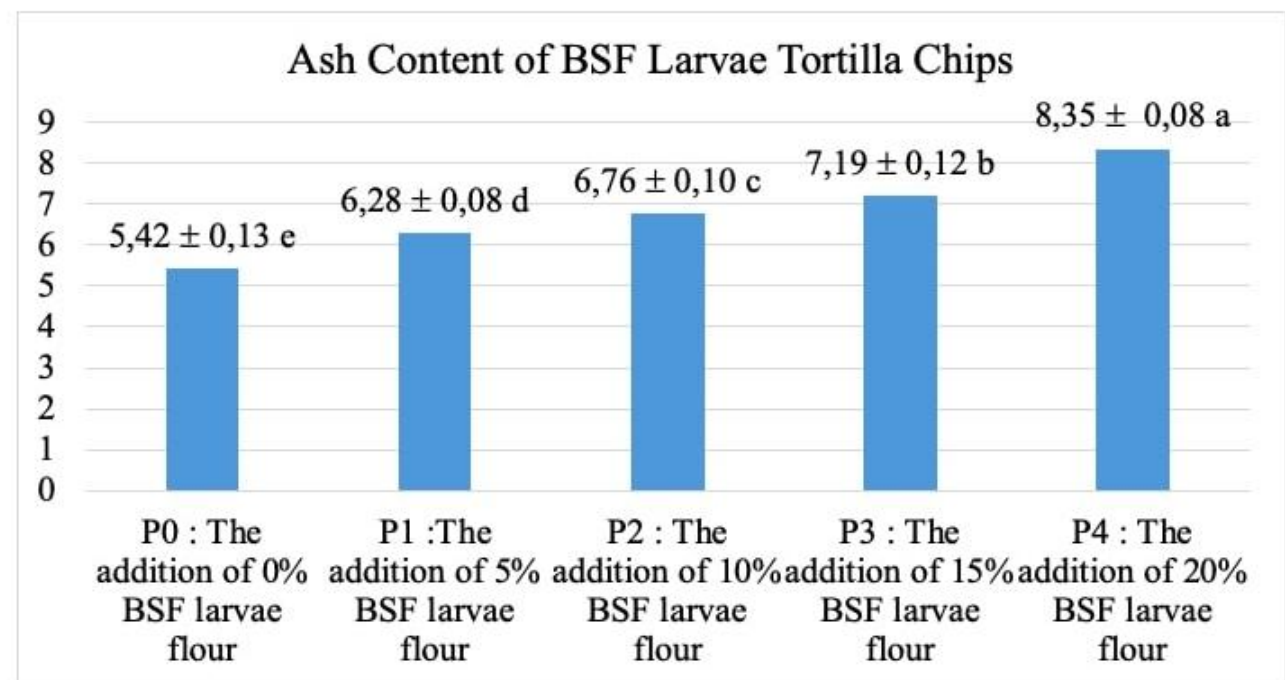

Description: The same letter below the average value in the column indicates a no different treatment, $(\mathrm{P}>0.05)$. 
Fig.3 Fat content of BSF larvae tortilla chips

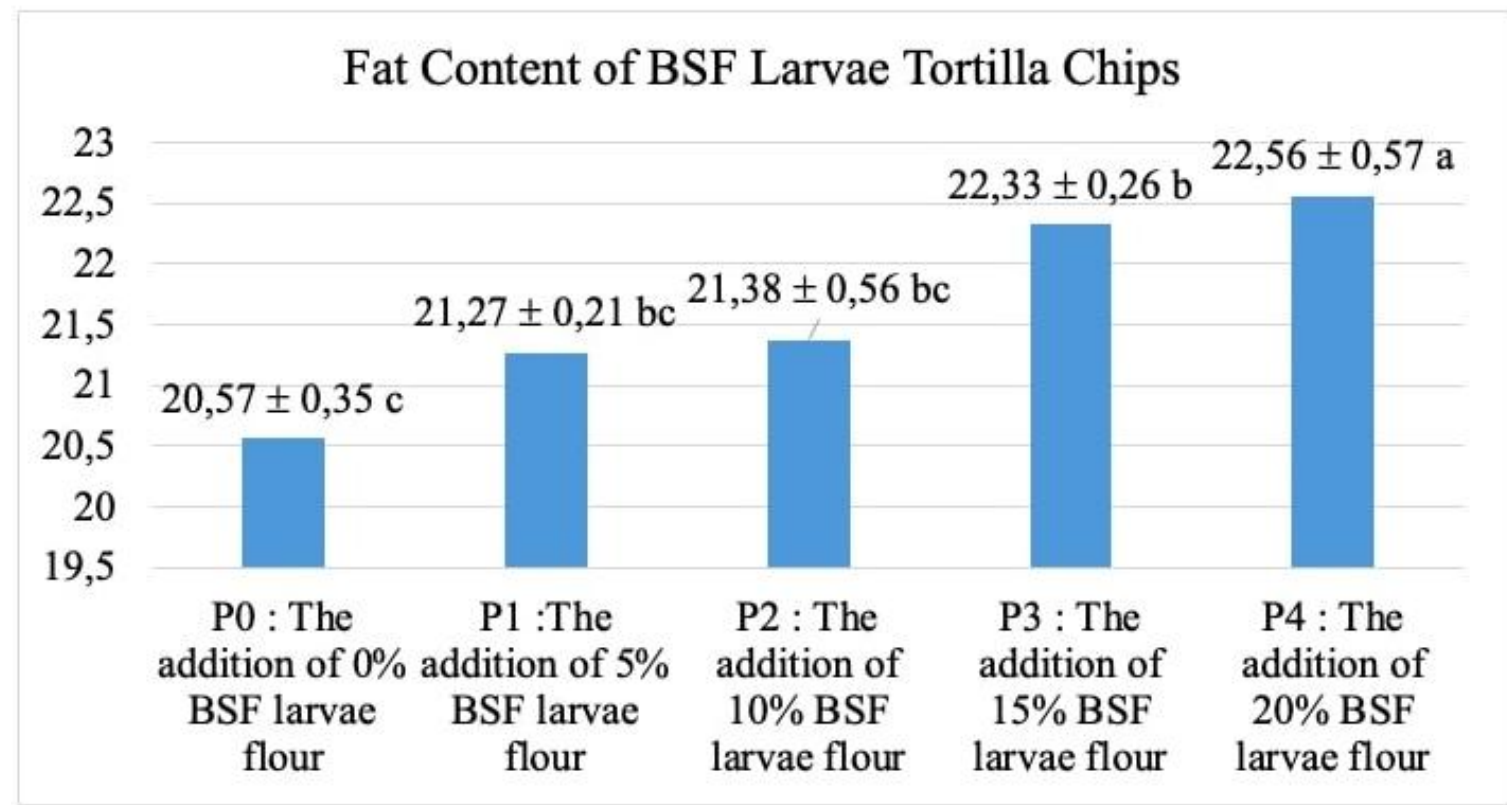

Description: The same letter below the average value in the column indicates a no different treatment, $(\mathrm{P}>0.05)$.

Fig.4 Protein content of BSF larvae tortilla chips

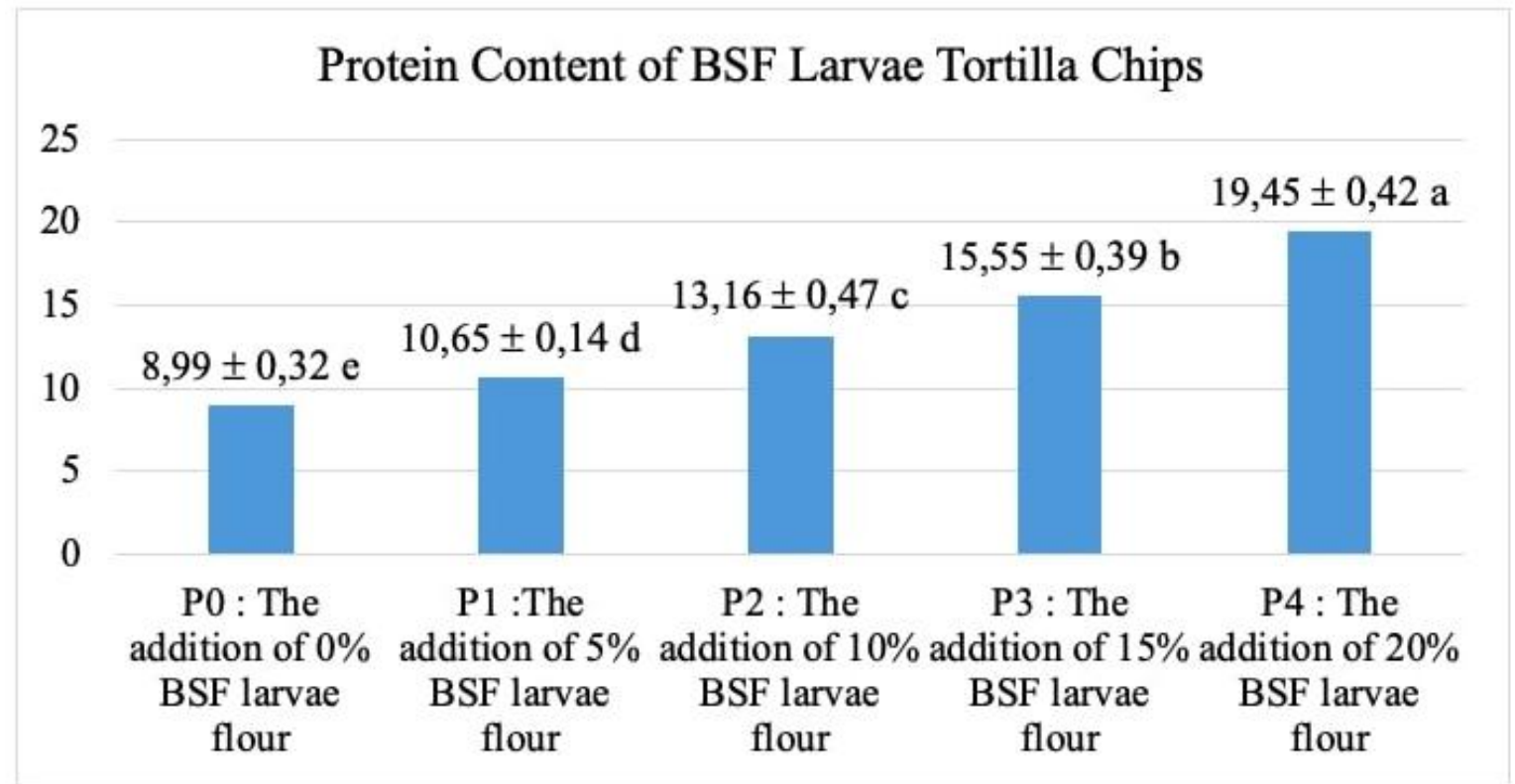

Description: The same letter below the average value in the column indicates a no different treatment, $(\mathrm{P}>0.05)$. 
Fig.5 Carbohydrate content of BSF larvae tortilla chips

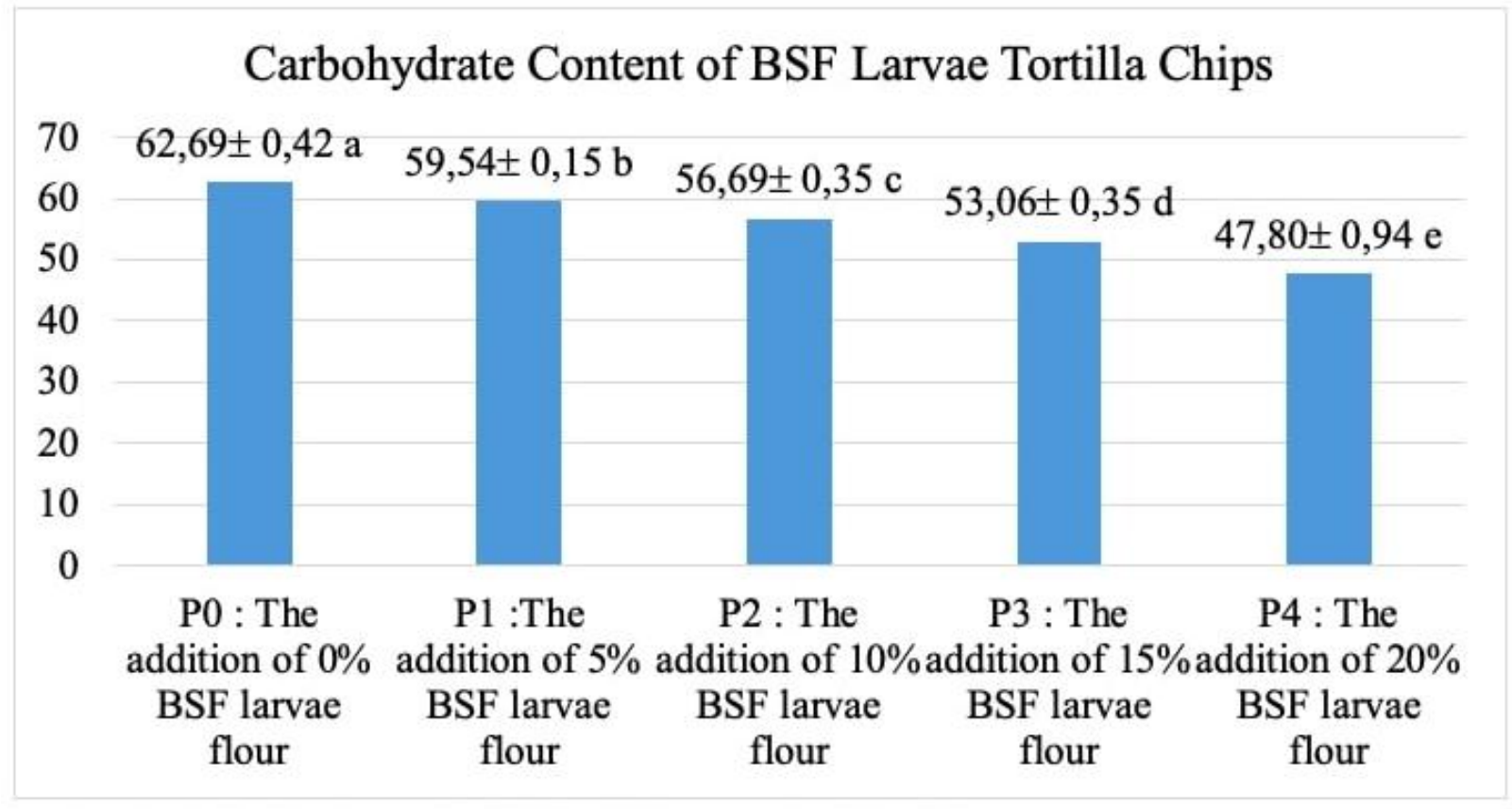

Description: The same letter below the average value in the column indicates a no different treatment, $(\mathrm{P}>0.05)$.

Fig.6 Crude fiber content of BSF larvae tortilla chips

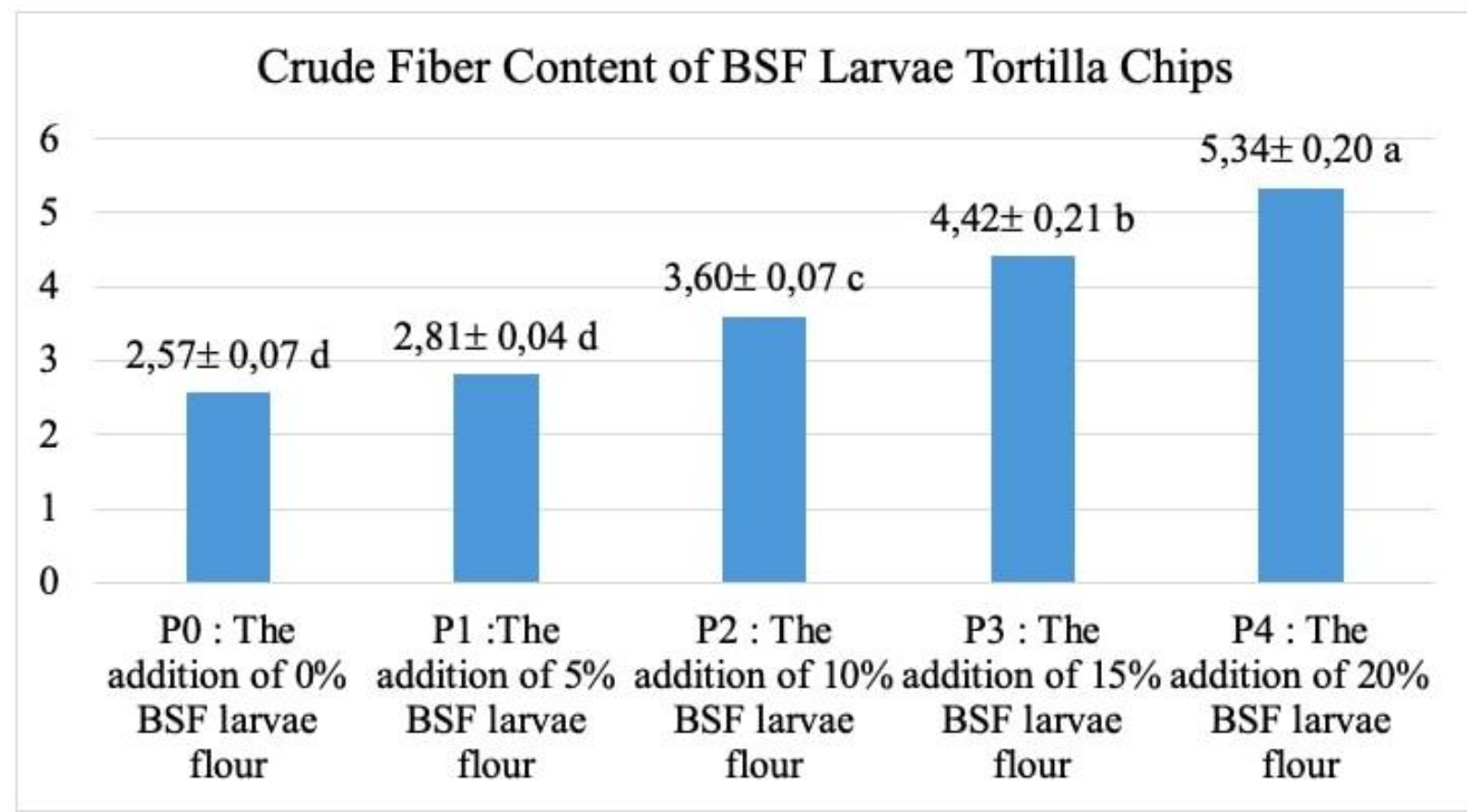

Description: The same letter below the average value in the column indicates a no different treatment, $(\mathrm{P}>0.05)$. 
Fig.7 Total plate count of BSF larvae tortilla chips

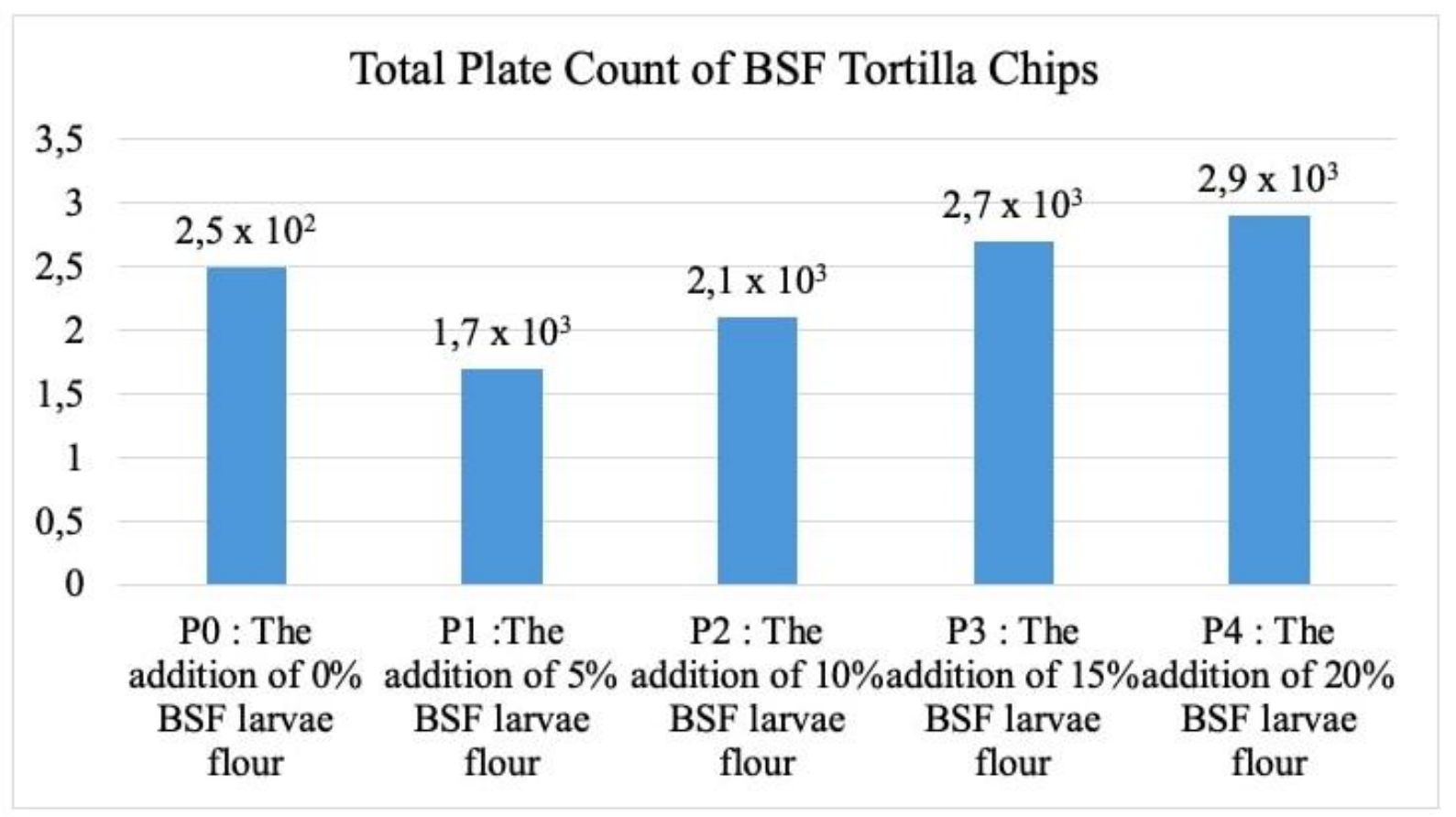

In terms of assessment criteria, the average value of the addition of BSF larvae flour various treatments in the produce of tortilla chips to the taste of the product gets the criteria of likes from panelists, it can be indicated that the panelists can receive the taste of tortilla chips products made using the addition of BSF larvae flour.

\section{Overall Acceptance}

The results of the analysis of variance of treatment of the addition of BSF larvae flour had a significance effect $(\mathrm{P}<0.05)$ to the overall acceptance of the resulting BSF larvae tortilla chip. Overall acceptance is a factor that includes the color, taste, texture, and aroma criteria of a product so that panelists can accept the product. The panelist's average of overall acceptance (hedonic) was obtained at the P0 treatment (No Addition of BSF larvae Flour) which is 4.6 (very like) and the average value for the lowest is obtained at the $\mathrm{P} 3$ treatment (Addition of 15\% BSF Larvae Flour) which is 3.9 (likes). This is likely because panelists are familiar with the consumption of tortilla chips made from corn compared to tortilla chips made with the addition of BSF larvae flour.

In terms of assessing the average value of the addition of BSF larvae flour various treatments in the produce of tortilla chips get the criteria of likes from panelists, it can be indicated that panelists can receive tortilla chips products made using the addition of BSF larvae flour.

\section{Color Score Test}

The results of the analysis of variance of treatments added BSF larvae flour had a very significance effect $(\mathrm{P}<0.01)$ against the color scoring test of the BSF larvae tortilla chip produced. The average panelist's average of color (scoring) was obtained at the P0 treatment (No Addition of BSF larvae Flour) which is 4.7 (very yellow) and the lowest average value is obtained on the $\mathrm{P} 4$ treatment (Addition of 20\% BSF larvae flour) is 1.4 (very brown). Results show that more additions of BSF larvae flour, Then it will influence the color obtained, the more addition 
of BSF larvae flour will give a more brown color to the tortilla chips produced. This is because the color characteristics of BSF larvae flour have a brown color.

\section{Texture Score Test}

The results of the analysis of variance of treatments added BSF larvae flour had a significance effect $(\mathrm{P}<0.05)$ against the texture scoring test of the BSF larvae tortilla chips produced. The average panelist's average of color (scoring) was obtained at the P0 treatment (No Addition of BSF larvae Flour) which is 3.9 (crispy) while the lowest average value is obtained at the P4 treatment (Addition of $20 \%$ BSF larvae Flour) which is 3.2 (neutral).

The results obtained show that the more addition of BSF larvae flour will affect the texture of the resulting BSF larvae tortilla chip, it can be seen from the level of crispness produced, the more addition of BSF larvae flour in the production of tortilla chips can cause the level of the crispness of the resulting tortilla chips product to decrease. The addition of BSF larvae flour as much as $20 \%$ is the best treatment as evidenced by the highest effectiveness index value of 0.66 . The proximate characteristics obtained in the treatment are moisture content of 1.84 \pm $0.19 \%$; ash content of $8.35 \pm 0.08 \%$; fat content of $22.56 \pm 0.57 \%$; protein levels by $19.45 \pm 0.42 \%$; carbohydrate content of $47.80 \pm$ $0.94 \%$; and crude fiber content of $5.34 \pm$ $0.20 \%$ and microbiological tests of total plate count with a value of $2.9 \times 10^{3}$ with an average sensory evaluation of color hedonic (3.0) and texture (3.5) with neutral criteria, and hedonic average score against taste (4.0), aroma (3.8), and overall reception (4.1) with like criteria as well as color score test (1.4) with very brown criteria and texture scoring test $(3,2)$ with ordinary criteria.

\section{Acknowledgments}

Thanks to PT.Bala Biotech Indonesia who fully funded this research and the Dean of the Faculty of Agricultural Technology and Mrs. Dr. Luh Putu Wrasiati. MP facilitated so that this research from program Akselerasi Start Up Mahasiswa Indonesia (ASMI), Minister of Education, Culture, Research and Technology Republic Indonesia can be finished.

\section{References}

Badan Standardisasi Nasional., 2000. SNI 012886-2000. Makanan ringan ekstrudat. Badan Standarisasi Nasional, Jakarta.

De Garmo, E. D., W. G. Sullivan and Canada J. R. 1984. Engineering Economis. Mc Millan Publishing Company. New York.

Fahmi, M. R., S. Hem dan Subamiya, I W. 2007. Potensi Larvae Sebagai Sumber Protein Alternatif.Prosiding Seminar Nasional Perikanan II. UGM, 5 hlm.

Harlystiarini. 2017. Pemanfaatan Tepung Larva Black Soldier Fly (Hermetia illucens) sebagai Sumber Protein Pengganti Tepung Ikan pada Ransum Puyuh Telur (Cortunix cortunix). Bogor: Institut Pertanian Bogor.

Muchtadi, R., Tien, dan Sugiyono. 1992. Ilmu Pengetahuan Bahan Pangan, IPB. Bogor.

Mudjajanto, E. E. dan Yulianti, L. N. 2004. Membuat Aneka Roti. Penerbit Swadaya. Jakarta.

Panjaitan, P. S., T. F. C Panjaitan, A. N Siregar dan Sipahitar, Y. H. 2020. Karakteristik Mutu Tortilla dengan Penmabhan Rumput Laut. Aurelia Jpurnal 2(1) : 71-84.

Piliang, W. G. dan S. Djojosoebagio. 2002. Fisiologi Nutrisi. Vol. I. Edisi Ke-4. IPB Press, Bogor.

Rabani, V., H. Cheatsazan dan Davani, S. 2019. Proteomics and lipidomics of 
black soldier fly (Diptera stratiomyidae) and blow fly (Diptera calliphoridae) larva. Jornal of Insect. 19(3).

Rohmayanti, T., N. Novidahlia dan Damayanti, I. 2019. Karakteristik tortilla chips dengan penambahan tepung ampas kecap. Journal Agroindustri Halal. 5(1) : 113-121.

Sediaoetama, A. D. 2008. Ilmu Gizi untuk Mahasiswa dan Profesi. Dian Rakyat. Jakarta.

Soekarto, S. T. 1985. Penilaian Organoleptik Untuk Industri Pangan dan Pertanian. Bharata Karya Aksara. Jakarta.

Sudarmadji, S., H., Bambang dan Suhardi.
1997. Prosedur Analisa untuk Bahan Makanan dan Pertanian. Edisi Ketempat. Liberty. Yogyakarta.

Sukmawati, Ratna dan Fahrizal, A. 2018. Analisis cemaran mikroba pada daging ayam broiler di kota makassar. Jurnal Scripta Biologica 5(1): 68-71.

Wahyuni, L. 2008. Komposisi Kimia Dan Karakteristik Protein Tortilla Corn Chips Dengan Penambahan Tepung Putih Telur Sebagai Sumber Protein.Skripsi. Tidak Dipublikasikan, IPB, Bogor.

Winarno, F. G. 2002. Kimia Pangan dan Gizi. Gramedia Pustaka Utama, Jakarta.

\section{How to cite this article:}

I Gusti Ayu Krisma Widya Saraswati, I Gede Arie Mahendra Putra and Luh Putu Wrasiati. 2021. The Effect of Adding Black Soldier Fly (BSF) Larvae (Hermetia illucens L.) Flour on the Characteristics of Tortilla Chips. Int.J.Curr.Microbiol.App.Sci. 10(12): 369-382.

doi: https://doi.org/10.20546/ijcmas.2021.1012.042 